\title{
Botanični terminološki slovar
}

\author{
Nina Ditmajer
}

Cobiss: 1.19

\begin{abstract}
Botanični terminološki slovar, ur. Franc Batič - Borislava Košmrlj - Levačič, Ljubljana: Založba ZRC, ZRC SAZU, 2011, 650 str.
\end{abstract}

Leta 2011 je izšel prvi slovenski botanični terminološki slovar, ki je nastal na pobudo Biotehniške fakultete Univerze v Ljubljani in ga je realizirala Sekcija za terminološke slovarje Inštituta za slovenski jezik Frana Ramovša ZRC SAZU v Ljubljani. Botanični terminološki slovar je normativni razlagalni terminološki slovar s tujejezičnimi ustrezniki. Uporabnik v njem lahko najde termine, povezane z zgradbo rastlinskih organizmov na celični, tkivni, organski ravni, nadalje so upoštevani termini, ki se nanašajo na rast, razvoj, razmnoževanje, na ekološke tipe rastlin, njihove združbe, na geografsko razširjenost itn. Slovar vsebuje imena višjih rastlinskih taksonov, ne pa tudi rastlinskih imen (imena za cvetlice), saj za ta že obstajajo specializirane publikacije, npr. Mala flora Slovenije (več izdaj). Slovar bo zanimiv za vse strokovnjake in tudi polstrokovnjake (študente), ki se ukvarjajo $\mathrm{z}$ naravoslovno vedo.

Vprašanje pouka $\mathrm{v}$ narodnih jezikih na srednjih šolah in potreba po slovenskih učbenikih je slovenske šolnike spodbujala $\mathrm{k}$ pospešenemu delu za učbenike, tudi $\mathrm{v}$ obliki prevodov iz nemščine. $\mathrm{V}$ teh okoliščinah je slovenski naravoslovec Ivan Tušek objavil Najbolj potrebne stvari iz botanične terminologije (1862), prevod Botanike (1875), njegov prevod dela Prirodopis rastlinstva s podobami, ki ga je napisal Alois Pokorny, pa velja za prvi slovenski srednješolski učbenik (poleg Erjavčevega Živalstva). Tuškove izraze za botaniko, fiziko in matematiko so najprej uporabili v svojih slovarjih Cigale, Janežič in Pleteršnik, iz njih pa so prešli v splošno besedje slovenskega jezika (Bufon 1980-1991: 259). Alfonz Paulin, takratni vodja Botaničnega vrta v Ljubljani, je leta 1898 napisal prvi izvirni učbenik za botaniko ter sodeloval pri Pleteršnikovem Slovensko-nemškem slovarju. Nato se je slovenska botanična terminologija začela hitreje razvijati vzporedno z razvojem šolstva na srednješolski in visokošolski ravni (Bevk 1927, Kapus 1937, Detela in Tomažič 1947, 1951, Detela 1960). Na botanično terminologijo je vplivala predvsem nemška botanična šola. Zlasti je bil pomemben Strasburgerjev učbenik botanike za visoke šole. Za razvoj botanične terminologije je pomembna revija Proteus, ki je začela izhajati leta 1933. Revija je v vseh letih izhajanja skrbela za pravilno botanično terminologijo. V drugi polovici 20. stoletja so zaradi finančnih omejitev, 
zaprtosti v ožje strokovne kroge, med katerimi ni bilo pravega sodelovanja, tudi ne z jezikoslovci, botanični univerzitetni učbeniki nastajali znotraj ožjih recenzentskih krogov. To se je spremenilo leta 2011, ko smo dobili Botanični terminološki slovar (BTS) (BTS: 7, 8).

Polni slovarski sestavek v BTS vsebuje iztočnico, zaglavje, strokovne oznake, definicijo, sopomenske izraze, razmerne izraze in na koncu tujejezične ustreznike. Prinaša kar 6729 slovarskih sestavkov, od tega je 1479 kazalčnih gesel. Vključuje tudi 5707 angleških, 6054 nemških in 1296 latinskih ustreznikov. Ker izhaja iz pojmovnega sistema, vanj niso vključeni glagoli, pridevniki in posamezne sestavine izrazov. Iztočnice so enobesedne ali večbesedne, praviloma zapisane z malo začetnico in v edninski obliki. V botanični terminologiji obstaja kar nekaj izrazov, ki so zgolj množinski, npr. rastlinska poimenovanja na nivoju debla, razreda, reda in družine. Taki izrazi so v slovarju zapisani v množinski obliki, v zaglavju pa vsebujejo tudi podatek o številu, in sicer $m n$. (= množina). Slovar slovenskega knjižnega jezika (dalje SSKJ) take izraze zapiše zgolj v edninski obliki ter jim v zaglavju slovarskega sestavka pripiše nav. mn. (= navadno v množini). BTS vsebuje tudi podvojene iztočnice, npr. Golgijev aparát -ega -a tudi golgijev apárat (izrazi, ki se uporabljajo v variantnih pisnih oblikah), kot iztočnice pa so upoštevane tudi kratice, npr. za izraz deoksiribonukleinska kislina se je uveljavila kratica DNK. Kratične iztočnice vsebujejo rodilniško obliko (zapisano z znakom --), v oglatem oklepaju sledi izgovarjava, nato podatek o nesklonljivosti, podatek krat. za kratico in puščica $(\rightarrow)$ k prednostni iztočnici. Kratice in okrajšave pri prednostni iztočnici so prikazane za skupno oznako K:, ki sledi zaglavju. Kot iztočnice so v slovarju upoštevani tudi izrazi z nelatiničnimi črkovnimi ali števčnimi sestavinami: $\alpha$-karoten 'alfakaroten', $\boldsymbol{Q 1 0}$ 'temperaturni koeficient'.

Po zgledu prejšnjih terminoloških slovarjev tudi BTS vsebuje puščične oznake. Enosmerna puščica, usmerjena v desno $(\rightarrow)$, nas vodi k prednostnemu izrazu, dvosmerna puščica pa nas usmerja k enakovrednemu izrazu $(\leftrightarrow)$. Uporaba dvosmerne puščice je sicer terminografska novost, ki je bila prvič uporabljena $\mathrm{v}$ Čebelarskem terminološkem slovarju (2008) zaradi besednih zvez, v katerih se navadno uporablja jedrni samostalnik z drugimi pojasnili. Primer takega izraza: membrána e ž cit. $\leftrightarrow$ biomembrána. Prav tako so z dvosmerno puščico prikazane zveze $\mathrm{z}$ desnim prilastkom, pri katerih izrazna podoba termina prav tako variira $\mathrm{v}$ svojih členih: $\boldsymbol{A T P}$-sintaza -e [atepé] ž (ang. Adenosine triphostate synthase) biokem., fiziol. $\leftrightarrow$ adenozín trífosfát sintáza. Novost v BTS je dvosmerna puščica, uporabljena pri kratičnih iztočnicah, ki se v besedilih pogosto pojavljajo, npr. $\boldsymbol{A} \boldsymbol{O} \boldsymbol{A}$-- [aoá] ž. neskl. (ang. Aminooxyacetic acid) krat. biokem., fiziol. $\leftrightarrow$ amínoóksiócetna kislina.

V terminologiji je zaradi jasnosti v komunikaciji zaželeno, da obstaja za določen pojem en izraz, a se pogosto znotraj iste stroke uporabljata dva ali več sopomenskih izrazov; to lahko opozarja na nedodelanost pojmovnega sistema znotraj stroke same (BTS: 9). Slovar vsebuje sopomenske izraze (za oznako S:), in sicer je kot prednosten izbran tisti izraz, ki je po jezikovnih in strokovnih merilih najustreznejši. Prednostni termini so prikazani s polnimi slovarskimi sestavki, neprednostni pa s kazalčnimi gesli. V slovar niso vključeni žargonski, zastareli ali starinski izrazi. Tako se zgodi, da tuji botanični izrazi, npr. eksina, intina, turgor, arhegonij 
itn. nimajo slovenske ustreznice, čeprav je bila v preteklosti že predlagana. Veliko je tudi takšnih izrazov, ki imajo prednost pred slovensko ustreznico, npr. embrio (kalček), pelod (cvetni prah), protalij (predkal), intercelular (medcelični prostor), hidrofit (vodna rastlina), plazmalema (celična membrana). BTS nima slovenske sopomenke niti za izraz mikropila, čeprav že Kmetijski tehniški slovar (1995) predlaga slovenski izraz ustje semenske zasnove, za izraz nucel predlaga izraz sredica semenske zasnove, za integument pa ovojnica semenske zasnove. Za oznako PRIM. so v slovarju navedeni pojmovno bližnji, torej priredni termini, za oznako GL. pa izrazi, ki kažejo hierarhična razmerja znotraj same pojmovne skupine. Tako sem spadajo podpomenke. S tem so dobro prikazana hierarhična razmerja med izrazi v slovarju.

BTS vsebuje kar 32 strokovnih označevalnikov. Z označevalnikom bot./botanika so opremljeni le splošni botanični pojmi, v slovarju pa najdemo tudi označevalnike s področja citologije, ekologije, biologije, agronomije, fizike, genetike, geologije, kemije, biokemije, varstva narave in tudi lesarstva. Tako bo slovar zanimiv tudi za uporabnike iz drugih naravoslovnih ved ter koristen za dopolnjevanje njihovih terminoloških slovarjev.

Razlaga vsebuje uvrščevalno pomensko sestavino, ki poimenuje nadredni pojem, navedbo bistvenih, za pojasnjevalni pojem značilnih lastnosti ter razlikovalno pomensko sestavino, ki določen pojem ločuje od prirednih pojmov. Npr. izraz iglavec je v BTS razložen kot drevesna vrsta z igličastimi listi, katerih življenjska doba traja eno vegetativno sezono, npr. pri macesnu (Larix), ali več vegetacijskih sezon, npr. pri smreki (Picea). PRIM.: listavec. V SSKJ je isti izraz razložen tako: iglasto drevo: gozd, les iglavcev; listavci in iglavci. Ugotovimo lahko, da BTS prinaša bogate razlage, ki jih dopolnjujejo konkretni primeri, ki so v SSKJ zapisani sicer za razlago. V tem konkretnem primeru lahko tudi vidimo, da razlage v BTS prinašajo tudi rastlinska imena in njihove latinske ustreznike, ki sicer niso obravnavani v samostojnih geselskih člankih.

Slovar vsebuje tudi slikovno gradivo iz fiziologije rastlin, kot so npr. oblike zoospor, oblike rež, tipi pelodnih zrn, mitohondrij, oblika dna listne ploskve idr., kar je pomembna dopolnitev slovarja in glede na ciljne uporabnike tudi primerna.

Glavni viri za BTS so bile dostopne strokovne publikacije v slovenščini in nekaterih tujih jezikih, za zgled pa so bili tudi terminološki slovarji v hrvaščini, angleščini in nemščini. Od slovenskih del je bilo upoštevanih pet srednješolskih učbenikov in eno poljudnoznanstveno delo. Slovenskih visokošolskih učbenikov je bilo upoštevanih bistveno več, 15 , ter eno spletno učno gradivo za študente. Od slovenskih terminoloških slovarjev so bili upoštevani tile: Kmetijski tehniški slovar (1995), Gozdarski slovar (1970), Geografski terminološki slovar (2005), Kmetijski tehniški slovar: vinogradništvo (1993), Slovenski medicinski slovar (2002), Les \& skorja (1990, slovar strokovnih izrazov) ter Okoljski pojavi in pojmi (2002). Od slovenskih strokovnih člankov je bilo upoštevanih pet člankov iz revij Les in Gospodarski vestnik. Drugo slovensko gradivo obsega razne priročnike, sezname, leksikone in strokovne ter znanstvene monografije.

Odkar je bila na Inštitutu za slovenski jezik Frana Ramovša ZRC SAZU ustanovljena Sekcija za terminološke slovarje, se zdi, da je bila biološka podsekcija 
- premalo aktivna. Na nesodelovanje znotraj same stroke in tudi z jezikoslovci opo-

[N zarjajo že uredniki slovarja. Zato smo izdaje Botaničnega terminološkega slovarja

N še toliko bolj veseli. Slovar je pomembno in bogato delo slovenske botanike, zato

- menimo, da se bodo po njem lahko zgledovale tudi druge naravoslovne vede. Nje-

ㅈ govi uporabniki bodo predvsem strokovnjaki in tudi polstrokovnjaki (študenti), saj

- avtorji upajo, da »bo slovar prispeval k odpravljanju strokovnih napak, ki so se

is pojavile v različnih strokovnih in poljudnostrokovnih publikacijah ter prevodih «

- (BTS: 8). Na koncu urednikom še predlagamo večje upoštevanje starejših sloven-

- skih del in člankov o botaniki, saj lahko slovar tako ponovno uvede slovensko ustre-

$<\quad$ znico za marsikateri tuji botanični izraz.

\section{Literatura}

Bufon 1980-1991 = Zmagoslav Bufon, Tušek Ivan, Slovenski biografski leksikon 4: Táborská-Žvanut, ur. Alfonz Gspan - Jože Munda - Fran Petrè, Ljubljana: SAZU, 1980-1991, 257-260.

SSKJ = Slovar slovenskega knjižnega jezika 1: A-H, 1970; 2: I-Na, 1975; 3: NePren, 1979; 4: Preo- $\check{S}, 1985 ; 5$ : $T-\check{Z}, 1$ 1991, Ljubljana: SAZU oz. (od 4. knjige naprej) SAZU - ZRC SAZU (izd.) - DZS (zal.). (Elektronska izdaja, 2008.) 